\title{
Peran Kantor Pertanahan dalam Kegiatan Pendaftaran Tanah Sistematis Lengkap
}

\author{
Oleh: \\ Mira Novana Ardani \\ Fakultas Hukum Universitas Diponegoro \\ miranovana@yahoo.com
}

\begin{abstract}
Abstrak
Pelaksanaan kegiatan Pendaftaran Tanah Sistematis Lengkap salah satunya merupakan kewajiban yang ditugaskan pada Badan Pertanahan Nasional, yang dilaksanakan oleh Kantor Pertanahan. Penelitian ini bertujuan untuk mengetahui bagaimana peran dari Kantor Pertanahan dalam kegiatan PTSL. Penelitian ini menggunakan pendekatan yuridis normatif. peran Kantor Pertanahan dalam kegiatan Pendaftaran Tanah Sistematis Lengkap sangatlah besar. Hal ini dapat dilihat dari tugas yang dimilikinya dalam setiap tahapan yang terdapat dalam pelaksanaan kegiatan Pendaftaran Tanah Sistematis Lengkap tersebut.
\end{abstract}

Kata kunci : Peran, Kantor Pertanahan, Pendaftaran Tanah Sistematis Lengkap 


\section{A. Pendahuluan}

\section{Latar Belakang}

Indonesia yang kaya akan sumber daya alamnya tentu saja merupakan anugerah dari Tuhan Yang Maha Esa yang tak ternilai. Tanah merupakan salah satu sumber kekayaan alam, yang mana menjadi modal dasar rakyat Indonesia. Modal tersebut tentu saja dapat digunakan sebagai pembangunan bagi kemajuan bangsa kita.

Pembangunan yang terkait dengan tanah, dapat dilihat baik dari dalam bidang infrastruktur untuk kepentingan umum, maupun pembangunan yang sifatnya untuk pribadi. Kepentingan umum yang dimaksud seperti yang tercantum dalam Pasal 10 Undang-Undang Nomor 2 Tahun 2012 tentang Pengadaan Tanah Bagi Pembangunan Untuk Kepentingan Umum, antara lain tanah yang digunakan untuk pembangunan pertahanan dan keamanan nasional, jalan umum, jalan tol, terowongan, jalur kereta api, stasiun kereta api, dan fasilitas operasi kereta api; waduk, bendungan, bendung, irigasi, saluran air minum, saluran pembuangan air dan sanitasi, dan bangunan pengairan lainnya; pelabuhan, bandar udara, dan terminal; infrastruktur minyak, gas, dan panas bumi; pembangkit, transmisi, gardu, jaringan, dan distribusi tenaga listrik; jaringan telekomunikasi dan informatika Pemerintah; tempat pembuangan dan pengolahan sampah; rumah sakit Pemerintah/Pemerintah Daerah; fasilitas keselamatan umum; tempat pemakaman umum Pemerintah/Pemerintah Daerah; fasilitas sosial, fasilitas umum, dan ruang terbuka hijau publik; cagar alam dan cagar budaya; kantor Pemerintah/Pemerintah Daerah/desa; penataan permukiman kumuh perkotaan dan/atau konsolidasi tanah, serta perumahan untuk masyarakat berpenghasilan rendah dengan status sewa; prasarana pendidikan atau sekolah Pemerintah/Pemerintah Daerah; 
prasarana olahraga Pemerintah/Pemerintah Daerah; dan pasar umum dan lapangan parkir umum.

Pembangunan yang sifatnya untuk memenuhi kepentingan pribadi, contohnya pembangunan rumah, dan perumahan. Kesemuanya, baik untuk pembangunan yang sifatnya untuk memenuhi kebutuhan publik, maupun pribadi, tentu saja memerlukan tanah. Tanah-tanah tersebut di Indonesia pengelolaannya ada pada Badan Pertanahan Nasional.

Kepemilikan tanah-tanah tersebut tentu saja perlu didukung dengan pengadministrasian yang tertib dan teratur. Cara yang dapat ditempuh yakni dengan melakukan pendaftaran tanah di seluruh wilayah Indonesia. Hal ini sesuai dengan amanah yang tertuang dalam Pasal 9 ayat (1) Undang-Undang Pokok Agraria, yakni untuk menjamin kepastian hukum oleh Pemerintah diadakan pendaftaran tanah di seluruh wilayah Republik Indonesia menurut ketentuan- ketentuan yang diatur dengan Peraturan Pemerintah.

Dalam rangka untuk menjalankan amanah tersebut, sejak tahun 2016 telah diterbitkan PeraturanMenteri Agraria dan Tata Ruang / Kepala BPN Nomor 28 Tahun 2016 tentang Percepatan Program Nasional Agraria melalui Pendaftaran Tanah Sistematis. Program nasional agraria yang selanjutnya disingkat PRONA tersebut memiliki pengertian program percepatan penetapan hak atas tanah dan pendaftaran tanah masyarakat yang dilaksanakan secara sistematis dan berkesinambungan desa/kelurahan demi desa/kelurahan di seluruh wilayah Republik Indonesia, sesuai dengan strategi pembangunan dari pinggiran.

Perkembangannya, untuk mewujudkan tujuan dari dilakukannya percepatan pendaftaran tanah lengkap di seluruh Republik Indonesia dirasa belum mengatur 
pemanfaatan tenaga profesional dan industri survei dan pemetaan, serta masih terbatasnya sumber-sumber pembiayaan dalam rangka pelaksanaan percepatan pendaftaran tanah lengkap, sehingga perlu disempurnakan, maka dikeluarkanlah PeraturanMenteri Agraria dan Tata Ruang / Kepala BPN Nomor 35 Tahun 2016 tentang Percepatan Pelaksanaan Pendaftaran Tanah Sistematis Lengkap.

Istilah PRONA, Program Nasional Agraria yang terdapat dalamPeraturanMenteri Agraria dan Tata Ruang / Kepala BPN Nomor 28 Tahun 2016 , sudah tidak ditemukan lagi dalam ketentuan umum PeraturanMenteri Agraria dan Tata Ruang / Kepala BPN Nomor 35 Tahun 2016. Istilah yang dapat ditemukan dalam PeraturanMenteri Agraria dan Tata Ruang / Kepala BPN Nomor 35 Tahun 2016 pada ketentuan umum Pasal 1 angka 1 nya yakni pendaftaran tanah sistematik lengkap, yang mempunyai makna kegiatan pendaftaran tanah untuk pertama kali yang dilakukan secara serentak yang meliputi semua obyek pendaftaran tanah yang belum didaftar dalam satu wilayah desa/kelurahan atau nama lainnya yang setingkat dengan itu.

Peraturan Menteri Agraria dan Tata Ruang / Kepala BPN Nomor 35 Tahun 2016 ternyata dinilai mengakomodir kebutuhan yang ada, maka aturan tersebut diubah dengan dikeluarkannya Peraturan Menteri Agraria dan Tata Ruang/Kepala Badan Pertanahan Nasional Nomor 1 Tahun 2017. Tidak berselang lama, peraturan menteri ini pun dicabut dan dinyatakan tidak berlaku dengan diterbitkannya Peraturan Menteri Agraria dan Tata Ruang/Kepala Badan Pertanahan Nasional Nomor 12 Tahun 2017 tentang Percepatan Pendaftaran Tanah Sistematis Lengkap, namun semua ketentuan pelaksanaan Peraturan Menteri Agraria dan Tata Ruang/Kepala Badan Pertanahan Nasional Nomor 35 Tahun 2016 tentang Percepatan Pelaksanaan Pendaftaran Tanah Sistematik Lengkap masih tetap berlaku sepanjang tidak bertentangan dengan ketentuan 
dalam Peraturan Menteri Agraria dan Tata Ruang/Kepala Badan Pertanahan Nasional Nomor 12 Tahun 2017.

Pada tahun 2018, muncul peraturan menteri kembali yakni Peraturan Menteri Agraria dan Tata Ruang/Kepala Badan Pertanahan Nasional Nomor 6 Tahun 2018 tentang Pendaftaran Tanah Sistematis Lengkap. Alasan adanya peraturan menteri ini karena masih terdapat beberapa permasalahan dalam pelaksanaan Peraturan Menteri Agraria dan Tata Ruang/Kepala Badan Pertanahan Nasional Nomor 12 Tahun 2017, sehingga memerlukan penyempurnaan substansi/materi dengan menyesuaikan pada ketentuan peraturan perundang-undangan yang mengatur tentang pendaftaran tanah maupun ketentuan pertanahan lainnya agar terselenggara pendaftaran tanah sistematis lengkap di seluruh wilayah Republik Indonesia.

Beberapa peraturan yang mengatur mengenai percepatan pendaftaran tanah tersebut, bertujuan untuk mewujudkan terselenggaranya pendaftaran tanah di seluruh wilayah Indonesia, yang kemudian saat ini disebut dengan Pendaftaran Tanah Sistematis Lengkap. Salah satu tujuannya untuk menjamin kepastian hukum. Hal ini tentu sangat memerlukan dukungan dari pemerintah itu sendiri. Dukungan tersebut dapat berupa peran yang ada pada Badan Pertanahan Nasional, dalam hal ini juga peran dari Kantor Pertanahan.

Berdasarkan hal diatas, maka permasalahan yang timbul dalam tulisan ini, bagaimana peran kantor pertanahan dalam kegiatan pendaftaran tanah sistematis lengkap?

\section{Metode Penelitian}

Penelitian ini menggunakan pendekatan yuridis normatif. Penelitian yuridis normatif memiliki makna penelitian yang difokuskan untuk mengkaji penerapan kaidah- 
kaidah atau norma-norma dalam hukum positif. ${ }^{1}$ Sedangkan yuridis normatif itu sendiri memiliki pengertian pendekatan yang menggunakan konsepsi legis positivis. Konsep ini memandang hukum identik dengan norma-norma tertulis yang dibuat dan diundangkan oleh lembaga atau pejabat yang berwenang. Konsepsi ini memandang hukum sebagai suatu sistem normatif yang bersifat mandiri, tertutup dan terlepas dari kehidupan masyarakat yang nyata. ${ }^{2}$

Penelitian ini menggunakan pendekatan perundang-undangan (statute aproach). Pendekatan tersebut digunakan untuk mengetahui keseluruhan peraturan hukum, khususnya mengenai hukum tanah di Indonesia.

Spesifikasi penelitian ini menggunakan penelitan deskriptif analitis, yaitu berupaya menggambarkan secara rinci bagaimana implementasi dari peraturanperaturan yang berhubungan dengan peran Kantor Pertanahan dalam kegiatan Pendafatran Tanah Sistematis Lengkap, tanpa melakukan hipotesa dan perhitungan secara statistik.

Jenis data yang dipergunakan yakni data primer, yaitu data yang diperoleh di lapangan sebagai data utama. Selain itu penggunaan data sekunder juga digunakan, yaitu diperoleh melalui studi kepustakaan, studi dokumenter maupun aturan-aturan hukum dalam peraturan perundang-undangan yang berfungsi untuk menunjang kelengkapan data primer. $^{3}$

Dalam metode pengumpulan data pada penulisan ini menggunakan data sekunder. Data sekunder tersebut mencakup dokumen-dokumen resmi, buku-buku perpustakaan, peraturan perundang-undangan, karya ilmiah, artikel-artikel, serta

\footnotetext{
${ }^{1}$ Johnny Ibrahim, 2006, Teori dan Metodologi Penelitian Hukum Normatif, Malang: Bayumedia Publishing, hlm. 295.

${ }^{2}$ Ronny Hanitijo Soemitro, 1988, Metodologi Penelitian Hukum dan Jurimetri, Jakarta: Ghalia Indonesia, hlm. 13-14

${ }^{3}$ Op.Cit,hlm.9
} 
dokumen yang berkaitan dengan materi penelitian. Bahan hukum sekunder tersebut mencakup tiga bagian, yaitu: ${ }^{4}$

1. Bahan hukum primer

Bahan hukum primer, yaitu bahan-bahan hukum yang mengikat.Bahan hukum primer yang digunakan dalam penelitian ini terdiri dari peraturan perundang-undangan yaitu Undang-Undang Pokok Agraria, Peraturan Menteri Agraria dan Tata Ruang/Kepala Badan Pertanahan Nasional, Instruksi Presiden, serta peraturan perundang-undangan lainnya yang dapat mendukung dalam penulisan ini.

2. Bahan hukum sekunder

Bahan hukum sekunder, yang memberikan penjelasan mengenai bahan hukum primer, seperti, hasil-hasil penelitian, hasil karya dari kalangan hukum, dan seterusnya.

\section{Bahan hukum tertier}

Bahan hukum tertier, yakni bahan yang memberikan petunjuk maupun penjelasan terhadap hukum primer dan sekunder; contohnya adalah kamus, ensiklopedia, indeks kumulatif dan seterusnya.

Metode pengumpulan data dalam penelitian ini dilakukan dengan studi pustaka, yaitu suatu cara pengumpulan data dengan melakukan penelusuran dan menelaah bahan pustaka (literatur, hasil penelitian, majalah ilmiah, buletin ilmiah, jurnal ilmiah, dan sebagainya). Hasil penelitian disajikan dalam bentuk uraian-uraian yang tersusun secara sistematis, artinya data sekunder yang diperoleh akan dihubungkan satu dengan yang

\footnotetext{
${ }^{4}$ Soerjono Soekanto dan Sri Mamudji, 2011, Penelitian Hukum Normatif, Suatu Tinjauan Singkat, Jakarta: Raja Grafindo Persada, hlm. 12
} 
lain disesuaikan dengan permasalahan yang diteliti, sehingga secara keseluruhan merupakan satu kesatuan yang utuh sesuai dengan kebutuhan penelitian.

Untuk menganalisis data yang diperoleh, akan digunakan metode analisis normatif, merupakan cara menginterpretasikan dan mendiskusikan bahan hasil penelitian berdasarkan pada pengertian hukum, norma hukum, teori-teori hukum serta doktrin yang berkaitan dengan pokok permasalahan. Norma hukum diperlukan sebagai premis mayor, kemudian dikorelasikan dengan fakta-fakta yang relevan (legal facts) yang dipakai sebagai premis minor dan melalui proses silogisme akan diperoleh kesimpulan (conclution) terhadap permasalahannya.

\section{Kerangka Teori}

Pendaftaran tanah di Indonesia dilaksanakan berdasarkan ketentuan Pasal 19 UUPA dengan peraturan pelaksanaannya Peraturan Pemerintah Nomor 24 Tahun 1997 tentang Pendaftaran tanah dan Peraturan Menteri Negara Agraria/Kepala Badan Pertanahan Nasional Nomor 3 Tahun 1997 tentang Ketentuan-Ketentuan Pelaksanaan PP No.24 Tahun 1997 tentang Pendaftaran Tanah.

Pengertian pendaftaran tanah menurut Peraturan Pemerintah Nomor 24 Tahun 1997 adalah rangkaian kegiatan yang dilakukan oleh pemerintah secara terus- menerus, berkesinambungan dan teratur, meliputi pengumpulan, pengolahan, pembukuan, dan penyajian serta pemeliharaan data fisik dan data yuridis, dalam bentuk peta dan daftar, mengenai bidang-bidang tanah dan satuansatuan rumah susun, termasuk pemberian surat tanda bukti haknya bagi bidangbidang tanah yang sudah ada haknya dan hak milik atas satuan rumah susun serta hak-hak tertentu yang membebaninya. 
Kewajiban melakukan pendaftaran tanah tersebut pada prinsipnya dibebankan kepada pemerintah dan pelaksanaannya secara bertahap daerah demi daerah berdasarkan ketersediaan peta dasar pendaftaran.Dalam kenyataannya di Indonesia, dari sekitar 55 juta bidang tanah yang ada, baru sekitar 30 persen yang bersertipikat. ${ }^{5}$

Sesuai dengan ketentuan yang terdapat dalam Pasal 19 UUPA, Pendaftaran tanah yang dilaksanakan di Indonesia merupakan pendaftaran tanah dalam rangka "Rechts kadaster", yaitu pendaftaran tanah yang tujuannya adalah dalam rangka untuk memberikan kepastian hukum dan perlindungan hukum kepada pemegang hak atas tanah, pada proses akhir pendaftaran tanah diterbitkan alat bukti berupan Buku Tanah dan sertipikat Tanah yang terdiri salinan Buku Tanah dan Surat Ukur.

Dalam rangka memberikan jaminan kepastian hukum dan perlindungan hukum hak atas tanah rakyat secara adil dan merata, serta mendorong pertumbuhan ekonomi negara pada umumnya dan ekonomi rakyat khususnya, serta untuk segera mewujudkan apa yang diamanahkan oleh Pasal 19 UUPA, bahwa pendaftaran tanah dilakukan diseluruh wilayah Republik Indonesia, maka dilakukan kegiatan percepatan pendaftaran tanah sistematis lengkap (PTSL) di seluruh wilayah Republik Indonesia.

Pengertian PTSL yang dapat kita temukan dalam Peraturan Menteri Agraria dan Tata Ruang/Kepala Badan Pertanahan Nasional Nomor 6 Tahun 2018 adalah kegiatan pendaftaran tanah untuk pertama kali yang dilakukan secara serentak bagi semua objek pendaftaran tanah di seluruh wilayah Republik Indonesia dalam satu wilayah desa/kelurahan atau nama lainnya yang setingkat dengan itu, yang meliputi pengumpulan data fisik dan data yuridis mengenai satu atau beberapa objek pendaftaran tanah untuk keperluan pendaftarannya.

\footnotetext{
${ }^{5}$ Maria SW Sumardjono, Kebijakan Pertanahan Antara Regulasi Dan Implementasi, (Jakarta, Kompas, 2006) hlm 201
} 
Maksud diadakannya Peraturan Menteri Agraria dan Tata Ruang/Kepala Badan Pertanahan Nasional Nomor 6 Tahun 2018 yaitu sebagai pedoman pelaksanaan kegiatan PTSL yang dilaksanakan desa demi desa di wilayah kabupaten dan kelurahan demi kelurahan di wilayah perkotaan yang meliputi semua bidang tanah di seluruh wilayah Republik Indonesia. Sedangkan tujuannya, sesuai dengan Pasal 2 aturan tersebut yaitu untuk mewujudkan pemberian kepastian hukum dan perlindungan hukum Hak atas Tanah masyarakat berlandaskan asassederhana, cepat, lancar, aman, adil, merata dan terbuka serta akuntabel,sehingga dapat meningkatkan kesejahteraan dan kemakmuran masyarakat dan ekonomi negara, serta mengurangi dan mencegahsengketa dan konflik pertanahan.

Objek PTSL meliputi seluruh objek pendaftaran tanah di seluruh wilayah Republik Indonesia, yang mana meliputi seluruh bidang tanah tanpa terkecuali, baik bidang tanah yang belum ada hak atas tanahnya maupun bidang tanah yang memiliki hak dalam rangka memperbaiki kualitas data pendaftaran tanah. Selain itu, dalam Pasal 4 ayat (3) objek PTSL juga meliputi bidang tanah yang sudah ada tanda batasnya maupun yang akan ditetapkan tanda batasnya dalam pelaksanaan kegiatan PTSL.

Kegiatan PTSL ini tentu saja melibatkan peran, mulai dari Kementerian Agraria dan Tata Ruang/Kepala Badan Pertanahan Nasional, kantor wilayah Badan Pertanahan Nasional, serta kantor pertanahan. Menurut Peraturan Presiden Nomor 20 Tahun 2015 tentang Badan Pertanahan Nasional Pasal 1 ayat (1), Badan Pertanahan Nasional (yang disingkat BPN) adalah Lembaga Pemerintah Non Kementerian yang berada di bawah dan bertanggung jawab kepada Presiden. Ayat (2) nya mengatakan BPN melaksanakan tugas pemerintahan di bidang pertanahan sesuai dengan ketentuan peraturan perundangundangan. 
Berdasarkan Peraturan Presiden Nomor 20 Tahun 2015, tugas pokok BPN adalah membantu presiden dalam mengelola dan mengembangkan administrasi pertanahan, baik berdasarkan UUPA, maupun peraturan perundang-undangan lainnya yang meliputi pengaturan, pengawasan pemilikan tanah, pengurusan hak-hak atas tanah, pengukuran, pendafatran tanah, dan lain-lain yang berkaitan dengan masalah-masalah pertanahan berdasarkan kebijaksanaan yang ditetapkan oleh presiden. ${ }^{6}$

\section{B. Hasil dan Pembahasan}

\section{Peran kantor pertanahan dalam kegiatan pendaftaran tanah} sistematis lengkap

Pendaftaran tanah di seluruh wilayah Negara Republik Indonesia diselenggarakan oleh pemerintah Indonesia, dalam rangka mengatur hubungan hukum antara subyek dan obyek bidang-bidang tanah. ${ }^{7}$ Untuk menjamin kepastian hukum oleh pemerintah diadakan pendaftaran tanah di seluruh wilayah Republik Indonesia menurut ketentuanketentuan yang diatur dengan peraturan pemerintah. Hal tersebut terdapat dalam Pasal 19 ayat (1) UUPA. Penyelenggaraan pendaftaran tanah tersebut merupakan instruksi yang diberikan kepada pemerintah, dalam hal ini Badan Pertanahan Nasional, yang pelaksanaannya ada pada Kantor Pertanahan.

Pelaksanaan PTSL, dalam rangka efisiensi dan efektivitas pelaksanaan kegiatannya, memerlukan peran dari BPN maupun kantor pertanahan. Tertuang dalam Pasal 6 Peraturan Menteri Agraria dan Tata Ruang/Kepala Badan Pertanahan Nasional Nomor 6 Tahun 2018, untuk menetapkan lokasi penyebaran target PTSL, Kepala

\footnotetext{
${ }^{6}$ Ali Achmad Chomzah, Hukum Pertanahan: Pengadaan Tanah Instansi Pemerintah, (Jakarta: Prestasi Pustaka, 2003), hlm.5

${ }^{7}$ Prama Widianugraha, : http://jurnal.fh.unpad.ac.id/index.php/ibmh/issue/archive, Tinjauan Normatif Pendaftaran Tanah Sistematis Lengkap Dikaitkan Pembentukan Aturan Peraturan PerundangUndangan, Jurnal Bina Mulia Hukum, Volume 3, Nomor 2, Maret 2019
} 
Kantor Pertanahan menetapkan lokasi tersebut pada beberapa desa/kelurahan dan/atau kecamatan, dan untuk Kepala Kantor Wilayah BPN menetapkan lokasinya pada beberapa kabupaten/kota dalam satu provinsi.

Penetapan lokasi yang dilakukan oleh Kepala Kantor Pertanahan tersebut dilakukan pada lokasi kegiatan PTSL di wilayah kerjanya, dapat dalam satu wilayah desa, atau kelurahan, atau secara bertahap dalam satu hamparan. Hal ini terdapat dalam Pasal 7. Apabila terdapat keadaan tertentu, Kepala Kantor Pertanahan dapat melakukan perubahan lokasi PTSL yang sudah ditetapkan, serta dibuatkan dalam bentuk keputusan Kepala Kantor Pertanahan tentang perubahan lokasi PTSL. Apabila terjadi penetapan perubahan lokasi tersebut, Kepala Kantor Pertanahan wajib melaporkan kepada Kepala Kantor Wilayah BPN dengan memberikan alasan tentang perubahan dimaksud, sesuai isi Pasal 8.

Tahap pelaksanaan PTSL selanjutnya yaitu tahap persiapan. Menurut Pasal 9, Kepala Kantor Pertanahan melakukan persiapan pelaksanaan kegiatan PTSL dengan menyiapkan: sarana dan prasarana pelaksanaan kegiatan PTSL, sumber daya manusia, kebutuhan transportasi, koordinasi dengan aparat pemerintah lainnya, dan alokasi anggaran. Setelah itu, sesuai Pasal 10, Kepala Kantor Pertanahan menyiapkan peta dasar pendaftaran yang berbentuk peta garis atau peta foto. Dalam hal peta dasar pendaftaran belum tersedia, Kepala Kantor Pertanahan menyiapkan peta lainnya yang digunakan sebagai peta kerja.

Dalam hal pembentukan dan penetapan Panitia Ajudikasi PTSL dan satuan tugas (Satgas), merupakan tugas dari Kepala Kantor Pertanahan, yang dituangkan dalam bentuk keputusan. Hal ini terdapat dalam Pasal 11. Panitia ajudikasi PTSL tersebut terdapat pula panitia yang berasal dari pegawai kantor pertanahan. Sebagai ketua 
merangkap anggota panitia ajudikasi PTSL dijabat oleh pegawai kantor pertanahan, wakil ketua bidang fisik merangkap anggota yang memahami urusan infrastruktur pertanahan, Wakil Ketua bidang yuridis merangkap anggota yang memahami urusan hubungan hukum pertanahan, sekretaris, serta anggota dari panitia ini juga berasal dari kantor pertanahan, sesuai kebutuhan.

Sesuai dengan isi Pasal 13, bahwa panitia ajudikasi PTSL dibantu oleh satgas fisik, satgas yuridis dan satgas administrasi. Dalam hal diperlukan, Kepala Kantor Wilayah BPN dapat menugaskan Aparatur Sipil Negara dari kantor wilayah BPN atau kantor pertanahan sebagai satgas fisik, satgas yuridis atau satgas administrasi untuk membantu pelaksanaan kegiatan PTSL di kantor pertanahan lain dalam satu wilayah provinsi.

Setelah dibentuk panitia ajudikasi PTSL, selanjutnya dalam Pasal 16, Kepala Kantor Pertanahan beserta panitia ajudikasi PTSL, Satgas Fisik dan Satgas Yuridis memberikan penyuluhan kepada masyarakat, baik yang sudah maupun belum memiliki sertipikat, serta kepada Pemerintah Daerah, instansi terkait, penegak hukum dan/atau tokoh-tokoh masyarakat.

Dalam hal pengumpulan data fisik dan pengumpulan data yuridis, Kepala Kantor Pertanahan harus memastikan kesesuaian data yang dihasilkan dari kegiatan PTSL dengan data elektronik dalam aplikasi KKP. Hal ini dijelaskan dalam Pasal 17. Selanjutnya, untuk keperluan pembuktian hak, panitia ajudikasi PTSL melakukan penelitian data yuridis., sesuai Pasal 22. Tahap selanjutnya yaitu pengumuman data fisik dan data yuridis serta pengesahannya. Pasal 24, untuk memenuhi asas publisitas dalam pembuktian pemilikan tanah, data yuridis dan data fisik bidang tanah dan peta bidangbidang tanah diumumkan dengan menggunakan formulir pengumuman data fisik dan data yuridis selama 14 (empat belas) hari kalender di Kantor Panitia Ajudikasi PTSL 
dan Kantor Kepala Desa atau Kelurahan. Setelah masa pengumuman berakhir, data fisik dan data yuridis disahkan oleh Panitia Ajudikasi PTSL yang dibuat dalam bentuk Berita Acara Pengesahan Pengumuman Data Fisik dan Data Yuridis.

Pada tahap penegasan konversi, pengakuan hak, dan pemberian hak, sesuai Pasal 26, dalam hal bidang tanah data fisik dan data yuridisnya memenuhi syarat untuk diterbitkan sertipikat hak atas tanah, maka akan ditindaklanjuti oleh Ketua Panitia Ajudikasi PTSL. Menurut Pasal 27, berdasarkan usulan keputusan pemberian hak, untuk bidang tanah yang merupakan tanah negara, Kepala Kantor Pertanahan menetapkan keputusan pemberian hak yang dilakukan secara kolektif dan memberikan catatan pada halaman terakhir daftar usulan pemberian Hak Milik/Guna Bangunan/Pakai.

Pasal 28, mengenai tahapan pembukuan hak, dalam hal penandatanganan buku tanah penegasan konversi dan pengakuan hak, penetapan keputusan pemberian hak, maka dibukukan hak milik, hak guna bangunan, hak pakai dan/atau wakaf dalam buku tanah yang bersangkutan, dilakukan oleh Ketua Panitia Ajudikasi atas nama Kepala Kantor Pertanahan. Selain itu, Pasal 29, dalam hal terdapat bidang tanah yang memenuhi syarat untuk diterbitkan sertipikat namun terdapat perkara di pengadilan, yang mana setelah mendapat putusan pengadilan yang berkekuatan hukum tetap, dan amar putusannya menyatakan salah satu pihak sebagai pihak yang berhak, ditetapkan setelah tahun anggaran kegiatan PTSL berakhir, maka Kepala Kantor Pertanahan yang menandatangani dan menerbitkan Sertipikat Hak atas Tanah, tanpa mengganti buku tanah yang telah ditandatangani Panitia Ajudikasi PTSL.

Sesuai isi Pasal 30, dalam hal bidang tanah yang data fisik dan data yuridisnya tidak dapat dibukukan dan diterbitkan Sertipikat Hak atas Tanah karena subjek dan/atau 
objek haknya belum memenuhi persyaratan tertentu, namun karena setelah dipenuhinya beberapa persyaratan, maka bidang tanah tersebut dapat dibukukan buku tanah dan diterbitkan sertipikat Hak atas Tanahnya kepada pihak yang berhak, maka penandatanganan penerbitan sertipikat Hak atas Tanah tersebut dilaksanakan oleh Kepala Kantor Pertanahan.

Penandatanganan sertipikat hak atas tanah hasil pelaksanaan kegiatan PTSL dilaksanakan oleh Ketua Panitia Ajudikasi PTSL untuk dan atas nama Kepala Kantor Pertanahan. Hal ini diatur dalam Pasal 31. Selain itu, terdapat kewajiban bagi Kepala Kantor Pertanahan menyampaikan daftar BPHTB terhutang dan/atau PPh terhutang tersebut secara periodik dalam waktu 3 (tiga) bulan kepada Bupati/Walikota setempat untuk BPHTB, kepada Kantor Pajak Pratama setempat untuk PPh, yang memuat identitas peserta (NIK), letak tanah, luas tanah, tanggal dan nomor sertipikat serta Nilai Jual Objek Pajak/surat keterangan pajak. Hal ini dijelaskan dalam Pasal 33.

Dalam hal pengumpulan, pengelompokan, pengolahan, dan penyimpanan data PTSL, dilakukan oleh Panitia Ajudikasi PTSL. Hal ini sesuai dengan Pasal 36. Setelahnya, menurut Pasal 37, Ketua Panitia Ajudikasi PTSL menyerahkan hasil pelaksanaan kegiatan PTSL kepada Kepala Kantor Pertanahan pada akhir kegiatan PTSL dan disertai dengan data PTSL, dibuat dalam bentuk Berita Acara Serah Terima berkas dan warkah hasil kegiatan PTSL yang ditandatangani oleh Ketua Panitia Ajudikasi PTSL dan Kepala Kantor Pertanahan. Hasil kegiatan PTSL disimpan, didokumentasikan dan diarsipkan oleh Kepala Kantor Pertanahan. Hal ini sesuai dengan Pasal 38.

Pelaporan, sesuai Pasal 39, dilakukan oleh Ketua Panitia Ajudikasi PTSL kepada Kepala Kantor Pertanahan dengan tembusan Direktur Jenderal Hubungan Hukum 
Keagrariaan dan Kepala Kantor Wilayah BPN jika terjadi permasalahan dalam pelaksanaan kegiatan PTSL. Sedangkan untuk pelaporan bahwa PTSL selesai dilaksanakan, dilakukan secara berjenjang dan berkala dari Kepala Kantor Pertanahan, Kepala Kantor Wilayah BPN, dan Menteri. Baik pelaporan jika terjadi permasalahan maupun pelaporan telah selesainya PTSL, ditandatangani oleh Kepala Kantor Pertanahan, untuk Kantor Pertanahan, dan Kepala Kantor Wilayah BPN, untuk Kantor Wilayah BPN. Penanggung jawab pelaksanaan laporan ada pada Kepala Kantor Pertanahan, untuk tingkat Kabupaten/Kota, dan Kepala Kantor Wilayah BPN, untuk tingkat Provinsi.

Dalam Pasal 41, pada bagian ketentuan lain-lain, terdapat ketentuan bagi penyelesaian permohonan hak dan pendaftaran hak yang sudah terdaftar di Kantor Pertanahan dalam lokasi pendaftaran tanah secara sistematis belum selesai pengurusannya, maka untuk permohonan hak yang sudah diperiksa oleh Panitia Pemeriksaan Tanah, penyelesaiannya dilakukan oleh Kepala Kantor Pertanahan, Kepala Kantor Wilayah BPN dan/atau Menteri sesuai dengan ketentuan peraturan perundangundangan, dan bagi permohonan pendaftaran hak yang berasal dari konversi yang sudah selesai diumumkan, penyelesaiannya dilakukan oleh Kepala Kantor Pertanahan dan/atau Kepala Kantor Wilayah BPN sesuai dengan ketentuan peraturan perundangundangan. Bagi permohonan yang tidak termasuk kedalamnya, berkasnya disampaikan oleh Kepala Kantor Pertanahan kepada Panitia Ajudikasi untuk diselesaikan sesuai Peraturan Menteri Agraria dan Tata Ruang/Kepala Badan Pertanahan Nasional Nomor 6 Tahun 2018. Proses permohonan hak dan pendaftaran asal konversi hak-hak lama wajib diberitahukan oleh Kepala Kantor Pertanahan kepada Panitia Ajudikasi dan sesuai keperluannya diserahkan warkah-warkahnya. 


\section{Simpulan}

Berdasarkan uraian di atas, maka dapat disimpulkan bahwa peran Kantor Pertanahan dalam kegiatan Pendaftaran Tanah Sistematis Lengkap sangatlah besar. Hal ini dapat dilihat dari tugas yang dimilikinya dalam setiap tahapan yang terdapat dalam pelaksanaan kegiatan Pendaftaran Tanah Sistematis Lengkap tersebut. Mulai dari tahap perencanaan sampai dengan pelaporan. Bahkan, untuk penyelesaian permohonan hak dan pendaftaran hak yang sudah terdaftar di Kantor Pertanahan dalam lokasi pendaftaran tanah secara sistematis belum selesai pengurusannya, dan bagi permohonan pendaftaran hak yang berasal dari konversi yang sudah selesai diumumkan tetap harus melalui penyelesaiannya pada Kantor Pertanahan. 


\section{Daftar Pustaka}

\section{A. Buku}

Achmad, Ali, Chomzah, 2003, Hukum Pertanahan: Pengadaan Tanah Instansi Pemerintah, Jakarta, Prestasi Pustaka

Hanitijo, Ronny, Soemitro, 1988, Metodologi Penelitian Dan Jurimetri, Jakarta, Ghalia

Ibrahim, Johnny, 2006, Teori dan Metodologi Penelitian Hukum Normatif, Malang, Bayumedia Publishing

Soekanto, Soerjono dan Mamudji, Sri, 2011, Penelitian Hukum Normatif Suatu Tinjauan Singkat, Jakarta, Raja Grafindo Persada

SW, Maria, Sumardjono, 2006, Kebijakan Pertanahan Antara Regulasi Dan Implementasi, Jakarta, Kompas

\section{B. Undang-Undang}

Undang-Undang Nomor 5 Tahun 1960 tentang Undang-Undang Pokok Agraria

Undang-Undang Nomor 2 Tahun 2012 tentang Pengadaan Tanah Bagi Pembangunan Untuk Kepentingan Umum

\section{Peraturan Pemerintah}

Peraturan Pemerintah Nomor 24 Tahun 1997 tentang Pendaftaran Tanah

\section{Peraturan Menteri}

Peraturan Menteri Agraria dan Tata Ruang/Kepala Badan Pertanahan Nasional Nomor 6 Tahun 2018 tentang Pendaftaran Tanah Sistematis Lengkap 